\title{
Prospective Market Diversification for Indonesian Plantation Commodities
}

\author{
Edy Rahmantyo Tarsilohadi \\ Fakultas Ekonomi, Universitas Bengkulu \\ \{edyrahmantyo@gmail.com\}
}

\begin{abstract}
Prospective market verification can bring benefits to Indonesian plantation commodities. With the assumption that there is a bad economic situation in one of the partner countries, the market diversification policy is a solution to be still absorbed by the market. This research provides a novelty, namely the study of Indonesian plantation commodities' competitiveness and development in the South American market. The South American region was chosen because the government has been aggressively cooperating with several countries included in the region in recent years. This study aimed to determine the dynamics of the competitiveness of Indonesian plantation commodities in the South American market. The method used is a descriptive analysis using secondary data from UN COMTRADE. The results showed that Indonesian plantation commodities in the South American market have high competitiveness and are prospective for continued marketing. However, there are several countries with a decreasing trend in imports. Therefore, it is necessary to research the factors that influence imports of the destination country from Indonesia.
\end{abstract}

Keywords: Competitiveness; Export Product Dynamics; Plantation Commodities; RCA South American Market

\section{Introduction}

In 2019, the Indonesian government will establish bilateral cooperation with Argentina. One of the agreements between the two parties is to increase exports from Indonesia to Argentina and vice versa. From the Indonesian point of view, the commodity that is emphasized is agricultural products. The market potential in Argentina is still wide open. Cooperation between Indonesia and Argentina has been established for a long time. The leaders of each country visited each other to strengthen ties for years ago. On a broader scale, the government can take advantage of this momentum to expand export destination countries' scope, namely the South American market [1]. The market diversification strategy to prospective markets can bring benefits, namely higher product absorption and anticipation if a partner country experiences economic constraints, then there are other markets to absorb available products [2].

South America consists of several countries, including Argentina, Bolivia, Brazil, Chile, Colombia, Ecuador, Guyana, French Guiana, Paraguay, Peru, Uruguay and Venezuela. The 
total population of South America in 2019 reached 427.02 million people. Based on this amount, South America needs a supply of agricultural products from other countries to meet its people's primary and secondary needs. It is an excellent opportunity for Indonesia considering that Indonesia is rich in natural resources.

Indonesia has a variety of superior export commodities, both food crops, horticulture and plantations. In the international market, Indonesia recorded more achievements in the plantation sub-sector crops, such as tea, pepper, crude palm oil and rubber. However, there is still minimal discussion about the potential for various agricultural products to be marketed in South America. It is the novelty of this research. Furthermore, this study aims to determine the dynamics of the competitiveness of Indonesian plantation products in the South American Market. By knowing this information, the information will be obtained regarding opportunities for prospective market diversification for Indonesian plantation commodities.

The competitiveness of a commodity means the commodity's ability to compete with the same commodities but originating from other regions. High competitiveness has implications for the product's continuous market absorption of these products. On the other hand, the relatively low competitiveness indicates that the consumption of these products is lower than the consumption of the same commodity from other regions. To determine the competitiveness of commodities, we can use Revealed Comparative Advantage (RCA). Several researchers used RCA to determine Indonesian tea's competitiveness in various international markets. RCA can be of value less than one and greater than one. Greater than one means that the commodity has competitiveness above the average of other regions within a specific range (for example, at the world level) [3] [4]..

On the other hand, a value less than one indicates that the commodity has weak competitiveness. Asmara and Artdiyasa [5], in their research to determine Indonesian plantation commodities' export competitiveness, results show that palm oil, cinnamon, pepper, cardamom/mace and vanilla have high competitiveness with RCA scores of 24.39, 24.6, $23.26,18.86$ and 17.46 respectively.

In connection with the dynamic development of international trade activities, information is needed on whether these commodities are competitive and have dynamic performance, are stagnant or slowing down. Zuhdi and Suharno [6] and Asmara and Artdiyasa [5], use Export Product Dynamics (EPD) to answer whether Indonesian and Vietnamese coffee is dynamic or not in the ASEAN market 5. Their research concludes that Indonesian coffee is classified as a rising star, which means that Indonesia's coffee export growth continues to increase as the share increases. Exports in ASEAN 5. Furthermore, Patone et al. [7] use EPD to determine Indonesia's competitiveness in China and India. Based on this study, it is known that Indonesian palm oil does not always have a competitive advantage because, in the span of the study, there was a fluctuation in position, sometimes up and also down.

\section{Research Method}

This study uses the primary descriptive analysis method, which describes an object based on the data that has been collected. The data in question is secondary data originating from UN COMTRADE from 2000 to 2019. The commodities that are the object of this study are tea (HS code 0902), pepper (HS code 0904), palm oil (HS code 1511) and rubber ( HS code 4001). In this study, the export destination countries are twelve countries, which are included in the South American Market (a total of 12 countries). To answer the research objectives, the calculation of RCA is used as an indicator of commodity competitiveness and EPD as a 
parameter in a commodity's export dynamics. For RCA, mathematically, it can be written as follows:

$$
\mathrm{RCA}=\frac{\left(\frac{\mathrm{Nij}}{\mathrm{Xt}}\right)}{\left(\frac{\mathrm{Wi}}{\mathrm{Wt}}\right)}
$$

Where Xij is the export value of commodity $\mathrm{i}$ from Indonesia to country $\mathrm{j}, \mathrm{Xt}$ is the world export value for commodity $\mathrm{i}$ to country $\mathrm{j}$, Wij is the total export value of all commodities from Indonesia to country $\mathrm{j}$, and $\mathrm{Wt}$ is the total export value of all commodities from all countries to countries $j$. An RCA value larger than one indicates commodity $i$ has competitiveness compared to the same commodity from other countries. Conversely, a value less than one indicates relatively weak competitiveness of commodity $i$.

Furthermore, the EPD calculation first looks for the X-axis (equation (2)) (growth in business power) and the $\mathrm{Y}$-axis (growth in market attractiveness). The $\mathrm{X}$-axis calculation is the ratio between the export of commodity $\mathrm{i}$ from Indonesia to the destination country (Xij) to the export of commodity $\mathrm{i}$ from the world to the destination country (Wij). The results of this ratio then become the basis for knowing the growth of $\mathrm{Xij}$ and Wij during the study (in this case, 2000 to 2019).

$$
\frac{\sum_{t=1}^{t}\left(\frac{X i j}{W i j}\right)_{t} \times 100 \%-\sum_{t=1}^{t}\left(\frac{X i j}{W i j}\right)_{t-1} \times 100 \%}{T}
$$

Furthermore, the $\mathrm{Y}$-axis is known by comparing all commodities from Indonesia to the destination country $(\mathrm{Xt})$ with world exports for all commodities in the world to the destination country $(\mathrm{Wt})$. As in the $\mathrm{X}$-axis, on the $\mathrm{Y}$-axis, the comparison of $\mathrm{Xt}$ and $\mathrm{Wt}$ becomes the basis for knowing each parameter's growth.

$$
\frac{\sum_{t=1}^{t}\left(\frac{X t}{W t}\right)_{t} x 100 \%-\sum_{t=1}^{t}\left(\frac{X t}{W t}\right)_{t-1} x 100 \%}{T}
$$

After the $\mathrm{X}$-axis and axis are known, then the results are combined with mapping the position of the commodity into four positions, namely rising star (positive $\mathrm{X}$ and $\mathrm{Y}$ values), lost opportunity ( $\mathrm{X}$ value less than zero and $\mathrm{Y}$ value greater than zero), falling star ( $\mathrm{X}$ value is negative while $\mathrm{Y}$ value is positive) and lost opportunity ( $\mathrm{X}$ value and $\mathrm{Y}$ value are negative). The combination of information from the RCA and EPD results will explain the dynamics of the competitiveness of Indonesian plantation commodities in the South American Market.

\section{Result and Discussion}

\subsection{RCA}

a) Tea 
In early 2000, not many countries in South America imported tea from Indonesia. One year later, Argentina began buying tea from Indonesia, and this continued into 2019, although in some years between that time, Argentina bought tea entirely from other countries. Judging from the competitiveness level, Indonesian tea in Argentina only once had high competitiveness, namely, in 2002. After that year, the performance of tea exports declined continuously.

The opposite happened in Brazil. In early 2000, Ecuador did not import tea from Indonesia at all. However, since 2003, the demand for Indonesian tea from Ecuador has increased drastically and even reached its highest point in 2007. After that year, the performance of Indonesian tea exports in Ecuador decreased and was correlated with the level of competitiveness which, on average, decreased over time. Time. Even so, the Indonesian tea commodity in Ecuador has relatively high competitiveness compared to other tea exporters.

Brazil, Peru, Suriname and Uruguay have the same trend; namely, in the last five years, Indonesian tea's level of competitiveness in the three countries has tended to decline.

Table 1. RCA Score of Tea (HS Code 0902)

\begin{tabular}{|c|c|c|c|c|c|c|c|c|c|c|c|c|}
\hline \multirow{2}{*}{ Year } & \multicolumn{12}{|c|}{ Counrty (ies) } \\
\hline & $\mathbf{A}$ & B & $\mathbf{C}$ & $\mathbf{E}$ & Bol. & G & Col. & Par. & $\mathbf{P}$ & $\mathbf{S}$ & $\mathbf{U}$ & $\mathbf{V}$ \\
\hline \multicolumn{13}{|l|}{2000} \\
\hline 2001 & $\begin{array}{c}0 . \\
29\end{array}$ & & & & & & & & & & & \\
\hline 2002 & 1. & 1.29 & & & & & & & & & & \\
\hline 2003 & & 1.71 & & 35.60 & & & & & & & & \\
\hline 2004 & $\begin{array}{c}0 . \\
22\end{array}$ & 7.18 & & $2,746.83$ & & & & & & & & \\
\hline $\begin{array}{l}2005 \\
2006\end{array}$ & & & & $\begin{array}{l}498.01 \\
709.30\end{array}$ & & & & & & & & \\
\hline 2007 & $\begin{array}{c}0 . \\
20\end{array}$ & & & $6,393.92$ & & & & & & & & \\
\hline 2008 & & & & $3,497.07$ & & & & & 0.04 & & & \\
\hline 2009 & $\begin{array}{c}0 . \\
08\end{array}$ & & & 840.11 & & & & & 0.09 & 14.42 & & \\
\hline 2010 & & 0.00 & & $1,232.42$ & & & & & 0.07 & 203.38 & & \\
\hline 2011 & & & & 155.85 & & & & & 0.06 & 480.71 & 0.01 & \\
\hline 2012 & & & & 440.84 & & & & & 0.08 & 476.52 & 0.00 & \\
\hline 2013 & & & & $1,790.71$ & & & & & 0.11 & $1,132.08$ & 0.04 & \\
\hline 2014 & & & & 409.07 & & & & & & 404.90 & 0.03 & \\
\hline 2015 & & & & 37.54 & & & & & 0.06 & & 0.21 & \\
\hline 2016 & & & & & & & 0.04 & & 0.03 & & 0.08 & \\
\hline 2017 & $\begin{array}{c}0 . \\
07\end{array}$ & & & & & & & & 0.04 & & 0.12 & \\
\hline 2018 & & 0.01 & & & & 859.27 & & & 2.44 & & 0.04 & \\
\hline 2019 & $\begin{array}{l}0 . \\
15\end{array}$ & 0.26 & & 94.34 & & & 0.00 & & 0.87 & 2.40 & 0.00 & \\
\hline
\end{tabular}

Source: Secondary data analysis, 2020

Note: $\mathrm{A}=$ Argentina; $\mathrm{B}=$ Brazil; $\mathrm{C}=$ Chile; $\mathrm{E}=$ Ecuador; Bol. = Bolivia; $\mathrm{G}=$ Guyana; Col. $=$ Colombia; Par. $=$ Paraguay; $\mathrm{P}=$ Peru; $\mathrm{S}=$ Suriname; $\mathrm{U}=$ Uruguay; $\mathrm{V}=$ Venezuela

\section{b) Pepper (HS Code 0904)}

In general, pepper is used as a cooking ingredient for both households and businesses in the culinary field. In the South American market, pepper from Indonesia tends to be 
unattractive, as indicated by its relatively small demand value. From 12 destination countries, Indonesian pepper was sent to 6 destination countries, namely Argentina, Bolivia, Colombia, Peru, Uruguay and Venezuela.

Compared to the six export countries in the South American market, Indonesian pepper's highest competitiveness is in Uruguay, followed by Venezuela and Argentina. Meanwhile, Peru and Colombia have shown decreasing performance. More than fifteen years ago, Indonesian pepper overcame the Peruvian and Colombian markets with relatively high export value. However, in the past few years, the export value has tended to decline, indicating that pepper competitiveness in the two countries is getting weaker.

Table 2. RCA Score of Pepper (HS Code 0904)

\begin{tabular}{|c|c|c|c|c|c|c|c|c|c|c|c|}
\hline \multirow{2}{*}{ Year } & \multicolumn{11}{|c|}{ Country (ies) } \\
\hline & $\mathbf{A}$ & $\mathbf{B}$ & C E & Bol. & $\mathbf{G}$ & Col. & Par. & $\mathbf{P}$ & $\mathbf{S}$ & $\mathbf{U}$ & $\mathbf{V}$ \\
\hline 2000 & 0.86 & & & & & & & 12.77 & & 12.58 & 2.88 \\
\hline 2001 & 1.20 & & & & & 1.81 & & 22.89 & & 6.86 & \\
\hline 2002 & & & & & & & & 40.72 & & & 6.86 \\
\hline 2003 & & & & & & & & & & & 4.86 \\
\hline 2004 & & & & & & & & & & & 1.42 \\
\hline 2005 & & & & & & & & 0.22 & & 34.68 & 9.63 \\
\hline 2006 & & & & & & 0.08 & & & & 64.95 & 8.62 \\
\hline 2007 & & & & & & 2.23 & & & & 68.96 & 15.04 \\
\hline 2008 & & & & & & 2.28 & & & & 67.63 & \\
\hline 2009 & & & & & & & & & & 73.45 & \\
\hline 2010 & & & & & & & & & & 39.14 & 4.03 \\
\hline 2011 & 1.36 & & & & & 2.35 & & & & 30.57 & \\
\hline 2012 & 1.86 & & & & & 0.91 & & & & 33.25 & \\
\hline 2013 & & & & & & & & 1.15 & & 69.08 & 39.70 \\
\hline 2014 & & & & & & & & & & 31.70 & \\
\hline 2015 & 2.65 & & & & & 1.16 & & & & 48.03 & \\
\hline 2016 & 5.89 & & & & & 0.35 & & & & 35.59 & \\
\hline 2017 & 2.76 & & & & & 0.35 & & 0.75 & & 60.26 & \\
\hline 2018 & & & & & & & & & & 52.93 & \\
\hline 2019 & & 0.00 & & & & 0.24 & & & & 0.00 & \\
\hline
\end{tabular}

\section{c) Palm Oil (HS Code 1511)}

Indonesia has a relatively large oil palm area, even in the country with the largest oil palm area in the world. It correlates with a high amount of palm oil production and processing. One of the processed palm products is palm oil. This commodity is consumed for various purposes ranging from household needs to fuel.

Based on RCA calculations, it is known that palm oil from Indonesia has relatively high competitiveness in Argentina, Brazil, Chile, Ecuador, Bolivia, Guyana, Colombia and Peru. Brazil is the country with the most consistent imports of palm oil from Indonesia than other South American countries. Meanwhile, Argentina, Guyana, Colombia have started importing from Indonesia in the last few years. It indicates that the penetration of Indonesian palm oil is getting deeper and broader. Market share increases continuously from year to year. 
Table 3. RCA Score of Palm Oil (HS Code 1511)

\begin{tabular}{|c|c|c|c|c|c|c|c|c|c|c|c|c|}
\hline \multirow{2}{*}{ Year } & \multicolumn{12}{|c|}{ Country (es) (HS Code 1511) } \\
\hline & $\mathbf{A}$ & B & $\mathbf{C}$ & $\mathbf{E}$ & Bol. & G & Col. & Par. & $\mathbf{P}$ & $\mathbf{S}$ & $\mathbf{U}$ & $\mathbf{V}$ \\
\hline 2000 & & 130.27 & & 435.96 & & & & & & & & \\
\hline 2001 & & 123.18 & & 902.55 & & & & & & & & \\
\hline 2002 & & 21.32 & & & & & & & & & & \\
\hline 2003 & & 28.95 & & 9.75 & & & & & & & & \\
\hline 2004 & & 46.29 & & & & & & & & & & \\
\hline 2005 & & 64.00 & & & & & & & & & & \\
\hline 2006 & & 90.82 & & $\begin{array}{c}200,221 \\
.82\end{array}$ & & & & & & & & \\
\hline 2007 & & 80.02 & & $\begin{array}{c}51,324 . \\
31\end{array}$ & & & & & & & & \\
\hline 2008 & & 90.90 & & & & & & & & & & \\
\hline 2009 & & 87.15 & & & & & & & & & 48.26 & \\
\hline 2010 & & 123.17 & & 153.66 & & & 8.00 & & 27.18 & & 9.49 & \\
\hline 2011 & & 85.03 & & & & 87.92 & 33.83 & & 34.93 & & 18.88 & \\
\hline 2012 & & 82.28 & 0.06 & & & 37.78 & 66.86 & & 138.91 & & 66.57 & \\
\hline 2013 & & 109.75 & & & & 98.64 & 32.07 & & 53.47 & & 72.11 & \\
\hline 2014 & & 96.26 & & & & & & & & & 21.18 & \\
\hline 2015 & 26.53 & 98.04 & 0.42 & & & 8.07 & & & 54.83 & & 14.41 & \\
\hline 2016 & 14.96 & 66.36 & & & & 11.66 & 4.00 & & 45.81 & & 23.01 & \\
\hline 2017 & 3.55 & 45.84 & & & & 8.77 & 0.00 & & 53.84 & & 24.69 & \\
\hline 2018 & 7.05 & 47.18 & 2.71 & & & 9.19 & & & 58.12 & & 28.27 & \\
\hline 2019 & 6.10 & 76.29 & 7.68 & 49.74 & & & & & 53.32 & & 98.77 & \\
\hline
\end{tabular}

Source: Secondary data analysis, 2020

\section{d) Natural rubber (HS Code 4001)}

Rubber plants cannot grow in all types of areas. One of the elements needed in rubber growth is the length of the sun's rays. Therefore, Indonesia has a comparative advantage over these characteristics. With a relatively large land area compared to other producing countries, Indonesia can market its products overseas. Based on RCA calculations, almost all countries were the object of research on rubber imports from Indonesia from 2000 to 2019. Of the nine countries that were consistently imported, Indonesian rubber's highest competitiveness was in Argentina, followed by Ecuador and Brazil. On the other hand, Guyana and Venezuela stopped importing rubber from Indonesia in 2013.

Table 4. RCA Score of Natural Rubber (HS CODE 4001)

\begin{tabular}{|c|c|c|c|c|c|c|c|c|c|c|c|c|}
\hline \multirow{2}{*}{ Year } & \multicolumn{12}{|c|}{ Country (ies) (HS Code 4001) } \\
\hline & $\mathbf{A}$ & B & $\mathbf{C}$ & $\mathbf{E}$ & Bol. & $\mathbf{G}$ & Col. & Par. & $\mathbf{P}$ & $\mathbf{S}$ & $\mathbf{U}$ & $\mathbf{V}$ \\
\hline 2000 & 65.64 & 48.54 & 57.46 & 118.37 & & 1.08 & 0.72 & & 1.61 & 5.24 & 3.55 & 0.29 \\
\hline 2001 & 68.04 & 72.19 & 96.37 & 270.18 & & 1.07 & 1.40 & & 1.09 & 9.96 & 3.86 & 0.15 \\
\hline 2002 & 84.16 & 35.49 & 101.77 & 282.00 & & 2.81 & 4.59 & & 2.34 & 0.30 & 2.65 & 0.18 \\
\hline 2003 & 79.21 & 46.48 & 127.83 & 210.98 & & 1.42 & 11.07 & & 2.14 & 1.49 & 1.30 & 8.31 \\
\hline 2004 & 86.09 & 49.92 & 95.55 & 140.47 & & 3.68 & 4.21 & & 1.29 & 2.06 & 1.43 & 6.69 \\
\hline 2005 & 117.30 & 41.60 & 98.96 & 393.64 & & 3.78 & 10.89 & 0.44 & 1.16 & 6.30 & 1.38 & 0.11 \\
\hline 2006 & 102.80 & 34.45 & 146.59 & 453.39 & & 13.76 & 8.95 & 1.06 & 1.26 & 2.51 & 1.25 & 0.38 \\
\hline 2007 & 106.42 & 37.39 & 67.94 & 431.03 & & 8.65 & 11.41 & 1.08 & 1.15 & 11.67 & 1.23 & 0.37 \\
\hline 2008 & 118.70 & 48.18 & 63.21 & 434.35 & & 6.39 & 16.78 & 0.84 & 0.94 & 3.58 & 0.89 & 0.69 \\
\hline 2009 & 135.42 & 48.59 & 19.02 & 474.19 & & & 13.61 & 1.69 & 1.46 & 4.82 & 0.52 & 2.36 \\
\hline 2010 & 115.36 & 52.71 & 78.76 & 488.61 & & 19.26 & 0.92 & 6.77 & 0.82 & 6.25 & 1.96 & 4.58 \\
\hline 2011 & 141.40 & 47.01 & 37.21 & 223.33 & & & 0.52 & 5.13 & 1.02 & 2.55 & 2.86 & 0.84 \\
\hline 2012 & 129.19 & 44.29 & 38.76 & 74.36 & & 6.44 & 0.58 & 7.24 & 1.13 & 1.69 & 3.90 & \\
\hline
\end{tabular}




\begin{tabular}{|c|c|c|c|c|c|c|c|c|c|c|c|c|}
\hline \multirow{2}{*}{ Year } & \multicolumn{12}{|c|}{ Country (ies) (HS Code 4001) } \\
\hline & $\mathbf{A}$ & B & $\mathbf{C}$ & $\mathbf{E}$ & Bol. & G & Col. & Par. & $\mathbf{P}$ & $\mathbf{S}$ & $\mathbf{U}$ & $\mathbf{V}$ \\
\hline 2013 & 126.93 & 51.73 & 31.95 & 94.47 & & & 1.24 & 8.89 & 1.15 & 8.63 & 2.62 & \\
\hline 2014 & 132.12 & 47.62 & 4.48 & 49.29 & & & & & & 6.13 & 2.10 & \\
\hline 2015 & 115.55 & 48.91 & 23.57 & 69.83 & & & 2.92 & 5.55 & 0.73 & 11.89 & 3.03 & \\
\hline 2016 & 131.28 & 44.13 & 73.01 & 85.11 & & & 1.62 & 4.33 & 0.72 & 23.65 & 1.88 & \\
\hline 2017 & 119.59 & 44.88 & 3.54 & 125.27 & & & 1.58 & 2.33 & 0.33 & 11.46 & 1.43 & \\
\hline 2018 & 114.13 & 52.70 & 0.58 & 110.03 & & & 3.10 & 2.31 & 0.53 & 10.83 & 2.36 & \\
\hline 2019 & 109.89 & 47.46 & 1.39 & 77.99 & & & 4.11 & & 0.53 & 1.55 & 3.22 & \\
\hline
\end{tabular}

Source: Secondary data analysis, 2020

\subsection{EPD}

Table 5 provides information on Indonesian plantation commodities (tea, pepper, palm oil and rubber) in the South American market. The X-axis describes the position of market attractiveness while the $\mathrm{Y}$-axis represents business strength information. Market attractiveness is calculated based on the growth in demand for plantation commodities in the destination country. At the same time, business strength is measured using the Indonesian market share's growth in the destination country [8],

The combination of market attractiveness $(\mathrm{X})$ and information on business strength $(\mathrm{Y})$ results in the status of each export commodity, namely the export market share growth category with positive value and positive value commodity market share growth (rising star), positive export market share growth and positive value. Growth of negative market share for commodities (falling star), growth in export market share with negative value and growth in market share for positive value commodities (lost opportunity) and growth in export market share with negative value and growth in market share for harmful value commodities (retreat) [8].

Among all commodities and destination countries, the highest predicate was LO (Lost Opportunity). This status indicates that exports have decreased when Indonesia's market share to destination countries shows a positive trend. Specifically in this study, the LO status could also be because Indonesia has never exported to the destination country. If this happens, it is necessary to further investigate the factors that cause delays in the export of plantation commodities to the destination country. In contrast, other export commodities are still being exported, and even the value tends to increase.

In the retreat (R) case, it was not only the plantation commodities that had not been able to be exported, or their export performance had decreased, but the total commodities had decreased. It becomes an evaluation for stakeholders. Does this occur due to internal factors such as relatively long export procedures, logistics costs, production capacity or due to external factors, one of which is an increase in the level of competition from other countries or relatively cheaper commodity prices from other countries.

Table 5. EPD Score of Plantation Commodities

\begin{tabular}{cccccccccc}
\hline $\begin{array}{c}\text { Country } \\
\text { (ies) }\end{array}$ & $\begin{array}{c}\text { HS } \\
\text { Code }\end{array}$ & $\mathbf{X}$ & $\mathbf{Y}$ & Status & $\begin{array}{c}\text { Country } \\
\text { (ies) }\end{array}$ & $\begin{array}{c}\text { HS } \\
\text { Code }\end{array}$ & $\mathbf{X}$ & Y & Status \\
\hline Argentina & 0901 & 0.00 & 2.98 & LO & Colombia & 0901 & 0.00 & 2.39 & LO \\
& 0902 & 0.00 & 2.98 & LO & & 0902 & 0.00 & 2.39 & LO \\
& 0904 & -20.32 & 2.98 & LO & & 0904 & 211.20 & 2.39 & RS \\
& 1511 & -5.41 & 2.98 & LO & & 1511 & 16.00 & 2.39 & RS \\
& 4211 & 4.95 & 2.98 & RS & & 4211 & 48.99 & 2.39 & RS \\
\hline Brazil & 0901 & 0.00 & 3.85 & LO & Paraguay & 0901 & 0.00 & 2.45 & LO \\
& 0902 & 0.00 & 3.85 & LO & & 0902 & 0.00 & 2.45 & LO \\
& 0904 & 0.00 & 3.85 & LO & & 0904 & 0.00 & 2.45 & LO
\end{tabular}




\begin{tabular}{cccccccccc}
\hline $\begin{array}{c}\text { Country } \\
\text { (ies) }\end{array}$ & $\begin{array}{c}\text { HS } \\
\text { Code }\end{array}$ & $\mathbf{X}$ & $\mathbf{Y}$ & Status & $\begin{array}{c}\text { Country } \\
\text { (ies) }\end{array}$ & $\begin{array}{c}\text { HS } \\
\text { Code }\end{array}$ & $\mathbf{X}$ & Y & Status \\
\hline & 1511 & 6.77 & 3.85 & RS & & 1511 & 0.00 & 2.45 & LO \\
& 4211 & 3.52 & 3.85 & RS & & 4211 & 43.68 & 2.45 & RS \\
\hline Chile & 0901 & 0.00 & -0.06 & R & Peru & 0901 & 453.64 & 3.67 & RS \\
& 0902 & 10.53 & -0.06 & FS & & 0902 & 0.00 & 3.67 & LO \\
& 0904 & 0.00 & -0.06 & R & & 0904 & 0.00 & 3.67 & LO \\
& 1511 & 0.00 & -0.06 & R & & 1511 & 60.55 & 3.67 & RS \\
& 4211 & 26.56 & -0.06 & FS & & 4211 & 1.82 & 3.67 & RS \\
\hline Ecuador & 0901 & 0.00 & 6.32 & LO & Suriname & 0901 & 0.00 & 0.79 & LO \\
& 0902 & 0.00 & 6.32 & LO & & 0902 & 158.37 & 0.79 & RS \\
& 0904 & 0.00 & 6.32 & LO & & 0904 & 0.00 & 0.79 & LO \\
& 1511 & 0.00 & 6.32 & LO & & 1511 & 0.00 & 0.79 & LO \\
& 4211 & 4.92 & 6.32 & RS & & 4211 & 78.26 & 0.79 & RS \\
\hline Guyana & 0901 & 0.00 & -0.01 & R & Uruguay & 0901 & 101.47 & 10.57 & RS \\
& 0902 & 0.00 & -0.01 & R & & 0902 & 18.99 & 10.57 & RS \\
& 0904 & 0.00 & -0.01 & R & & 0904 & 2.90 & 10.57 & RS \\
& 1511 & 12.77 & -0.01 & FS & & 1511 & 44.85 & 10.57 & RS \\
& 4211 & 0.00 & -0.01 & R & & 4211 & 37.75 & 10.57 & RS \\
\hline
\end{tabular}

Source: Secondary data analysis, 2020

Note $:$ LO : Lost Opportunity; RS = Rising Star; R = Retreat; FS = Falling Star

Falling star or FS describes these commodities as having a positive performance when the percentage of Indonesia's total export value to the destination country decreases compared to the total imports of the destination country. This growth supports Indonesia's overall export performance from these destination countries. In the latter status, namely rising star, Indonesia's market share increases, followed by commodity exports growth. This status is an ideal condition that is expected by business actors and other stakeholders.

\section{Conclusion}

Based on the studies that have been carried out, plantation commodities (tea, pepper, palm oil and rubber) have dynamic competitiveness from time to time in the South American market. Furthermore, plantation commodities also have great potential to be marketed to destination countries, which have not been the main focus (prospective market diversification).

\section{References}

[1] Khoiriyah. (2016). KEPENTINGAN INDONESIA KERJASAMA DENGAN ARGENTINA DALAM KERANGKA FEALAC (FORUM FOR EAST ASIA-LATIN AMERICA COOPERATIONS). JOM FISIP, 3(2).

[2] Setyawati, D., Oktaviani, R., \& Novianti, T. (2014). PRODUK EKSPOR PROSPEKTIF INDONESIA KE PERU DAN FAKTOR-FAKTOR PENENTU ALIRAN PERDAGANGANNYA KE KAWASAN AMERIKA SELATAN. Jurnal Ekonomi Dan Kebijakan Pembangunan, 3(2), 158-176.

[3] Satryana, M. H., \& Karmini, N. L. (2016). ANALISIS DAYA SAING EKSPOR TEH INDONESIA KE PASAR ASEAN PERIODE 2004-2013. E-Jurnal EP Unud, 5(5), 598-613. 
[4] Oktaviana, N., Masyhuri, \& Hartono, S. (2016). Competitiveness of Tea Exports in Asean : A Constant Market Share Analysis. Ilmu Pertanian, 1(2), 88-93.

[5] Asmara, R., \& Artdiyasa, N. (2008). ANALISIS TINGKAT DAYA SAING EKSPOR KOMODITI PERKEBUNAN INDONESIA. AGRISE, VIII(2).

[6] Fadhlan, Z., \& Suharno. (2015). Analisis Daya Saing Ekspor Kopi Indonesia Dan Vietnam Di Pasar ASEAN 5. Habitat, 26(3), 152-162. file://C:/Users/Adilla/Downloads/208-667-2-PB.pdf

[7] Patone, C. D., Kummat, R. J., \& Mandeij, D. (2020). ANALISIS DAYA SAING EKSPOR SAWIT INDONESIA KE NEGARA TUJUAN EKSPOR TIONGKOK DAN INDIA. Jurnal Berkala Ilmiah Efisiensi, 20(03), 22-32.

[8] Hakam, L. I. F. (2019). Analisis Daya Saing Dan Faktor-Faktor Yang Memengaruhi Permintaan Batu Bara Indonesia Di Negara Tujuan Ekspor Utama. Diponegoro Journal of Economics, volume 1., 31-45. 